\title{
Orobanche laxissima Uhlich \& Rätzel (Orobanchaceae) - a new species for Dagestan (Russia) and Azerbaijan
}

\author{
Renata Piwowarczyk ${ }^{1 *} \&$ Ivan Tatanov $^{2}$
}

${ }^{1}$ Department of Botany, Institute of Biology, Jan Kochanowski University, Świętokrzyska 15, 25-406 Kielce, Poland ${ }^{2}$ V. L. Komarov Botanical Institute, Russian Academy of Sciences, Prof. Popova St. 2, Saint Petersburg 197376, Russia

* corresponding author (e-mail: renka76@wp.pl)

\begin{abstract}
Orobanche laxissima Uhlich \& Rätzel (Orobanchaceae) is a probably endemic Caucasian parasite of trees. New localities of this species are reported from the Greater Caucasus: Russia (Dagestan) and Azerbaijan. These are the easternmost sites known for the species, so they extend its distribution range. Its hosts, abundance, and habitat preferences at the new localities are described, and a supplemented map of distribution of this species in Caucasus Mts. is provided.
\end{abstract}

Key words: Orobanche laxissima, distribution, habitat, host, Caucasus, Russia, Dagestan, Azerbaijan

\section{Introduction}

The Caucasus is located at the border of Europe and Asia, between the Caspian and Black Seas. Politically it is divided between Georgia, Armenia, Azerbaijan, and the North Caucasian portion of the Russian Federation (including the Dagestan, Chechnya, Ingushetia, northern Ossetia, Kabardino-Balkaria, Karachay-Cherkesia, and Adygea Autonomous Republics), the north-eastern part of Turkey, and a part of north-western Iran. Topographically the Caucasus comprises the Greater Caucasus (with the highest peak Mt. Elbrus, $5642 \mathrm{~m}$ a.s.l.), the Lesser Caucasus (up to $4000 \mathrm{~m}$ ), the South Caucasian Uplands (covering parts of Asia Minor, Armenian and Iranian uplands), and the Transcaucasian Depression, between the Greater and Lesser Caucasus. Caucasian flora comprises 6350 native species of vascular plants, 1600 of which are endemic. There are 17 endemic genera of plants in this region, 9 of which are associated with high mountain ecosystems (Holubec \& Křivka 2006).

The Caucasus and mountains of Central Asia are centres of origin of the genus Orobanche L. In this area, 70-85 species of this genus are known, and many of them are endemic. Distribution of the genus Orobanche and related genera and their hosts is still not sufficiently known (Rätzel \& Uhlich 2004).
Orobanche laxissima Uhlich \& Rätzel was first described from the Republic of Adygea (NW Caucasus, Russia), near the village of Novoprokhladnoye. It was considered to be probably endemic to the Caucasus Mts. Its distribution apparently is restricted to the foothills of the Caucasus Mts., especially Adygea (Maykopsky District), Krasnodar Krai, Stavropol Krai, to the Turkish coast of the Black Sea and Georgia (Kakheti region). Previously, it was known from about 20 localities (Rätzel \& Uhlich 2004; www.orowiki.org), but probably the species is most common within the Caucasus.

The aim of this paper is to describe new localities of Orobanche laxissima in the Caucasus Mts. Its taxonomy, biology, ecology, and distribution are also briefly discussed below.

Herbarium acronyms are given after Holmgren \& Holmgren (1998). Authors abbreviations of taxa are taken from Brummitt \& Powell (1992).

\section{Taxonomic problems, biology, and ecology}

Taxonomic notes

Orobanche laxissima Uhlich \& Rätzel, Feddes Repert. 115 (1-2): 194, 2004.

Syn. Orobanche fraxinii Uhlich in sched.

Typus: Russia, in Caucaso boreo-occidentali (Adygaea) prope pagum Novoprokhladnoye, ca. $700 \mathrm{~m}$ 
a. s. 1., in fruticetis, leg. S. Rätzel, 30.06.2002 n. 2334

(B; Isotypi 2333, 2335, Herbarium Rätzel).

Orobanche laxissima belongs to the grex Minores Beck, characterized by calyx teeth filiform, narrow and long (cf. description of calyx Rätzel \& Uhlich 2004). $O$. laxissima resembles $O$. crenata Forsk. or $O$. owerinii (Beck) Beck (parasitizing Fabaceae), mainly in stigma colour, lips and venation of the corolla. Unfortunately, in the original description of $O$. laxissima the colour of glandular hairs on the corolla is not mentioned. The photographs in www.orowiki.org, as well as authors' photographs and herbal material clearly show that hair colour is pale, white or bright yellow. This excludes O. laxissima from the grex Glandulosae Beck, containing e.g. O. reticulata Wallr. and $O$. alba Stephan ex Willd.

In spite of its distinctive habit, it has been confused in the literature with another species occurring in similar habitats, namely, $O$. hederae Duby (parasite of Hedera helix L. and H. colchica (K. Koch) K. Koch). $O$. laxissima has quite a distinctive habit, pink or deep purple flowers (20-24 mm long) with yellow colouring inside the corolla. Shoots deep pink, violet or purple, often yellow or light yellow (Fig. 1). Many species of the genus Orobanche, e.g. O. alba, O. alsatica Kirschl., O. bartlingii Griseb., O. caryophyllacea Sm., O. hederae group, are often yellow, but the yellow forms almost never constitute the majority of a population. Such coloration is not typical and is a result of low insolation, soil $\mathrm{pH}$, or incomplete plant pigmentation. Yellow and albinotic forms usually occur in shaded sites (Halamski 2011; Halamski \& Piwowarczyk 2008; Piwowarczyk $2011,2012)$, perhaps also when the parasite grows on untypical or weakened hosts. A detailed description of the species with photos has been provided by Rätzel \& Uhlich (2004).

Host plants: mostly Fraxinus excelsior L., F. pennsylvanica Marshall, Carpinus orientalis Mill., Cornus mas L., Ligustrum vulgare L. (Rätzel \& Uhlich 2004).

Habitat, plant communities, and a bundance : moist, shady or semishady places in deciduous forests, parasitic on roots of woody plants in the submontane zone (ca. 250-950 m a. s. 1.), usually in communities of the alliance Carpinion orientalis, the Querco pubescenti-Carpinetum orientalis, with some species from the association Pistacio muticae-Juniperetum excelsae. Orobanche laxissima occurs most often in large groups of about 100 up to 2000 shoots (Rätzel \& Uhlich 2004; www.orowiki.org).

Flow ering period: (May) June to July.
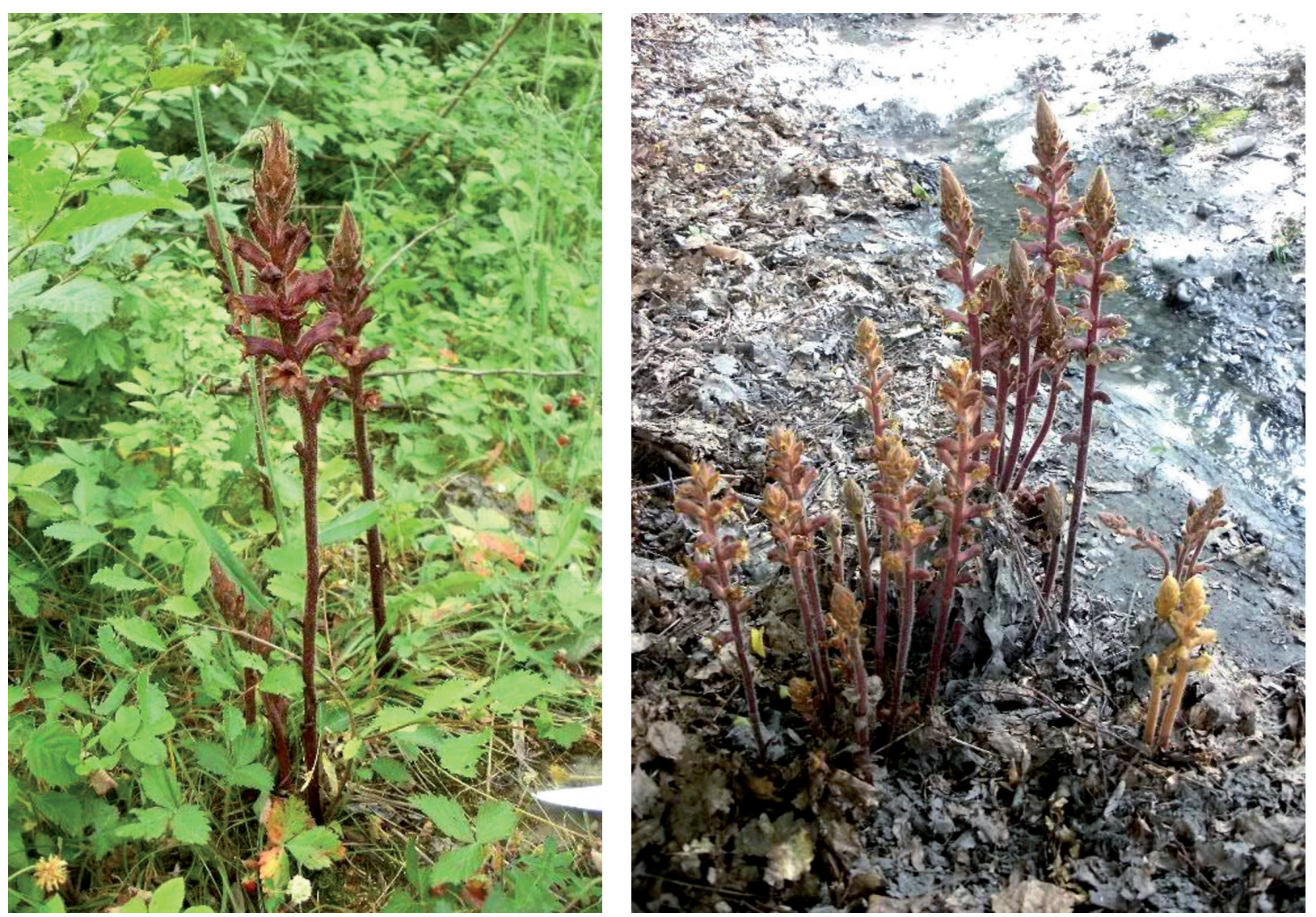

Fig. 1. Plant habit of Orobanche laxissima in Gabala (Azerbaijan) (photograph by I. Tatanov, 9 June 2012) 


\section{Results}

During a revision of the genus Orobanche in the herbarium LE in Saint Petersburg in 2013, the first author (RP) found $O$. laxissima (labelled as Orobanche sp.) collected together with the hosts Carpinus L. and Ligustrum L. from Russia (Dagestan) and Azerbaijan (Fig. 2).

New localities. Russia: Dagestan, Tabasaran District, left bank of the river Rubas-chai above the village of Huchni, in bushes on a slope. Corolla dirtypink, yellowish inside (with a host: Ligustrum), 23 June 1961, leg. N. N. Tzvelev, S. K. Cherepanov, G. N. Nepli, A. E. Bobrov (LE, 1681); Azerbaijan: Gabala Hanlar ("Russian forest"), 1400-1500 m, near a stream (with hosts: Carpinus and Ligustrum), 9 June 2012, leg. L. I. Krupkina, B. I. Tatanov, B. B. Svanova (LE).

\section{Conclusions}

Orobanche species parasitic on roots of trees, characterized by generally narrow distribution ranges, are most often endemic. For example, O. lucorum A. Braun ex Koch is a parasite of Berberis L., rarely Crataegus or Rubus L., and occurs only in alpine sites of the Central Alps [the species is occasionally cultivated in botanical gardens (Halamski 2005; Piwowarczyk \& Kirpluk 2011)]; O. sogdiana Novopokrovskij, parasitic on Amygdalus L., is endemic to Pamir-Alay (Novopokrovskij \& Tzvelev 1958; Kabulov 1978); O. transcaucasica Tzvelev, parasitic on Rhus coriaria L., is endemic to the Caucasus (Novopokrovskij \& Tzvelev 1958; Carlón et al. 2005); while O. ebuli Huter \& Rigo, on Sambucus ebulus L., is endemic to Italy, restricted to the districts of Abruzzi and Lazio (Lattanzi et al. 1999).

New localities of Orobanche laxissima reported from the Greater Caucasus in Russia (Dagestan) and Azerbaijan are the easternmost sites known for this species, so they extend its distribution range. The discovered localities are situated in the highest altitudes of the occurrence O. laxissima in the Caucasus. Parasiting on shrubs and trees as a phenomenon is rare among the Orobanche, so another example of $O$. laxissima is very interesting and valuable. Probably, more populations of this species can be found in the Caucasus Mts.

Acknowledgements. We thank curators of the herbarium in Sankt Petersburg (LE) for providing us with herbarium materials. We are also grateful to Holger Uhlich for confirmation of species identification. This work was supported by the Polish State Committee for Scientific Research (grant no. N N303 551939).

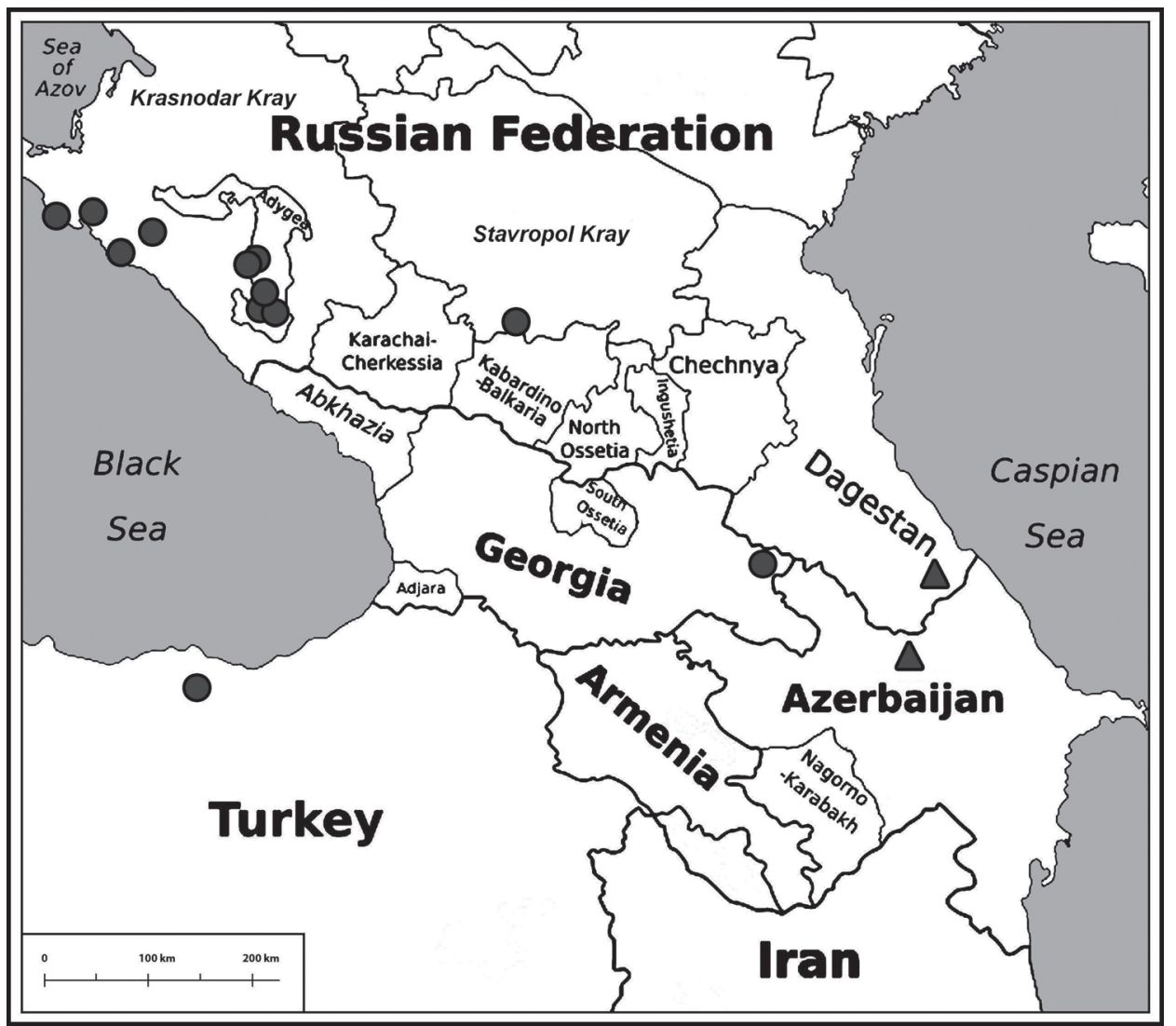

Fig. 2. Distribution of Orobanche laxissima in the Caucasus Mts. (after Rätzel \& Uhlich 2004; www.orowiki.org; modified and supplemented) Explanations: $\boldsymbol{\Delta}$ - new locality, $\bullet$ - earlier locality 


\section{References}

Brummitt R. K. \& Powell C. E. (eds.). 1992. Authors of Plant Names. 732 pp. Royal Botanic Gardens, Kew.

Carlón L., Gómez C., Laínz M., Moreno Moral G. M., Sánchez Pedraja Ó. \& Schneeweiss G. M. 2005. Más, a propósito de algunas Orobanche L. y Phelipanche Pomel del oeste del Paleártico. Documentos Jardín Botánico Atlántico Gijón 3: 1-71.

Halamski A. T. 2005. Orobanche lucorum introduced in the Botanical Garden of Warsaw University. Biuletyn Ogrodów Botanicznych 14: 115-117.

Halamski A. T. 2011. Orobanche hederae Vaucher ex Duby (Orobanchaceae) - plasticité phénotypique et micromorphologie des graines. Bull. mens. Soc. linn. Lyon 80(7-8): 170-178.

Halamski A. T. \& Piwowarczyk R. 2008. Graines d'Orobanches comme critere taxonomique-information sur les travaux en cours. Bull. mens. Soc. linn. Lyon 77(3-4): 37-40.

Holmgren P. K. \& Holmgren N. H. 1998. Index Herbariorum. New York Botanical Garden; http://sciweb.nybg.org/ science2/IndexHerbariorum.asp.

Holubec V. \& KŘIvka P. 2006. The Caucasus and its flowers. 390 pp. Loxia, Pardubice.

Kabulov D. T. 1978. Zarazichovye Srednej Azii. 66 pp. Tashkent.
Lattanzi E., Minutillo F. \& Tilia A. 1999. Segnalazioni floristiche italiane: 932. Orobanche ebuli Huter et Rigo. Informatore Botanico Italiano 31(1-3): 81.

NovopokrovskiJ I. V. \& Tzvelev N. N. 1958. Orobanchaceae. In: Flora SSSR, vol. 23, pp. 19-117, 685-687. Moscow-Leningrad.

Piwowarczyk R. 2011. Orobanche mayeri (Suess. \& Ronniger) Bertsch \& F. Bertsch - a species new to Poland. Acta Soc. Bot. Pol. 80(3): 179-183.

PiwowarczyK R. 2012. Orobanche alba subsp. alba and subsp. major (Orobanchaceae) in Poland: current distribution, taxonomy, plant communities, hosts, and seed micromorphology. Biodiv. Res. Conserv. 26: 23-38.

Piwowarczyk R. \& KirPluk I. 2011. Orobanche flava (Orobanchaceae) w Ogrodzie Botanicznym Uniwersytetu Warszawskiego. Fragm. Flor. Geobot. Polonica 18(1): 163-165.

Rätzel S. \& Uhlich H. 2004. Orobanche benkertii sp. nov. (Orobanchaceae Vent.) und weitere OrobancheSippen aus dem Nordwest-Kaukasus. Feddes Repertorium 115(1-2): 189-211.

www.orowiki.org 